\title{
O DIREITO À PRIVACIDADE: UMA REFLEXÃO ACERCA DO ANTEPROJETO DE PROTEÇÃO DE DADOS PESSOAIS'
}

\author{
THE RIGHT TO PRIVACY: A REFLECTION ON THE PRELIMINARY \\ DRAFT PROTECTION OF PERSONAL DATA
}

Bruno Mello Correa de Barros ${ }^{2}$

Clarissa Teresinha Lovatto Barros ${ }^{3}$

Rafael Santos de Oliveira ${ }^{4}$

\begin{abstract}
RESUMO: Este artigo se propōe a refletir a respeito do princípio da privacidade e demonstrar a premência da aprovaçăo de regra coerente sobre a proteçăo de dados pessoais no Brasil, compreendendo que, com Dworkin, princípio representa um fechamento hermenêutico capaz de buscar na integridade do próprio direito suas características. Utilizou-se como metodologia a ontologia hermenêutica, adotando a fenomenologia hermenêutica a fim de compreender a realidade e a temática proposta. Os métodos de procedimento elencados foram o método monográfico e o histórico. Desse modo, aponta-se que a privacidade e as suas formas de proteçấo costumam estar alinhadas à tecnologia disponível e que, com a consolidaçăo da Sociedade Informacional guiada, notadamente pela Internet e a circulaçâo instantânea de dados que ela propicia, o tema da proteçăo jurídica necessita de um marco regulatório integrado ao panorama internacional.
\end{abstract}

PALAVRAS-CHAVE: Direito à Privacidade. Proteçâo de Dados Pessoais. Integridade normativa.

ABSTRACT: This article proposes to reflect on the principle of privacy and demonstrate the urgency of the adoption of a coherent rule on the protection of personal data in Brazil, understanding that with Dworkin, principle represents a hermeneutic closure capable of seeking in the integrity of its own right characteristics.

1 Pesquisa conta com o apoio da Coordenaçăo de Aperfeiçoamento de Pessoal de Ensino Superior - CAPES.

2 Mestre em Direito pelo Programa de Pós-Graduaçăo - UFSM. Bacharel em Direito pelo Centro Universitário Franciscano - UNIFRA. Pesquisador do Centro de Estudos e Pesquisas em Direito \& Internet. brunomellocbarros@gmail.com

3 Advogada, jornalista e Mestre pelo programa de Pós Graduaçấo em Direito da UFSM e pesquisadora do grupo de estudos no Núcleo de Direito Informacional (NUDI). Formada em Direito e Jornalismo pela Universidade Federal de Santa Maria, além de MBA em Comunicaçăo Empresarial pela Universidade de Santa Cruz do Sul (2005/2006).clovatto@yahoo.com.br

4 Doutor em Direito pela Universidade Federal de Santa Catarina. Mestre em Integraçáo LatinoAmericana (Direito da Integraçáo) pela Universidade Federal de Santa Maria e Graduado em Direito pela Universidade Federal de Santa Maria (2003). Professor Adjunto III no Departamento de Direito da Universidade Federal de Santa Maria (UFSM) e no Programa de Pós-graduaçăo em Direito da UFSM (Mestrado). Professor do Curso de Especializaçâo em Agricultura Familiar Camponesa e Educaçáo do campo- Residência Agrária (2014/2015).advrso@gmail.com 
Hermeneutical ontology was used as methodology, adopting the hermeneutic phenomenology in order to understand the reality and the proposed theme. The methods of procedure listed were the monographic and historical method. Thus, it is pointed out that privacy and its forms of protection are usually in line with available technology and that, with the consolidation of the Information Society guided, notably through the Internet and the instantaneous circulation of data that it provides, the subject of legal protection Requires a regulatory framework integrated to the international scene.

KEYWORDS: right to privacy, personal data protection, normative integrity.

\section{INTRODUÇÃO}

Na perspectiva deste artigo, o direito à privacidade impóe-se como direito fundamental, destacando que a correlaçăo entre o nível de proteçáo desejado e o nível de tutela efetivo exige uma quota de privacidade, garantida por regra. As maneiras tradicionais de proteçăo se tornam difíceis em decorrência de características atinentes à sociedade informacional, revelando a premência de mecanismos que nâo se restrinjam a regras jurídicas nacionais e estejam integrados ao panorama internacional.

Destaca-se que este trabalho se propôe a refletir a respeito do princípio da privacidade e demonstrar a premência da aprovaçáo de regra coerente sobre a proteçâo de dados pessoais no Brasil, compreendendo, com Dworkin, que princípio representa um fechamento hermenêutico capaz de buscar na integridade do próprio direito suas características. Assim, o princípio năo representa "abertura" ao sujeito solipsista ou um mecanismo jurídico para preencher lacunas, haja vista que esse termo solipsista, derivado do alemáo, traduz-se em "viciado em si mesmo", ou seja, àquele que se utiliza por si só a própria expertise para resoluçăo de determinada situaçăo.

Ainda, em relaçáo aos autores que contribuem para construçâo deste artigo, recorreu-se ao entendimento de Pérez Luño (2005) de transposiçăo da percepçăo que separa intimidade e privacidade, tendo em vista a aceleraçăo provocada pela inovaçáo tecnológica e científica que permeia a contemporaneidade. Apropriou-se, também, dos ensinamentos Stefano Rodotà (2008) de que há a necessidade de ampliar o conceito de privacidade para além da dimensâo individualista.

A fim de possibilitar a melhor compreensăo da temática abordada, se estruturou este artigo em duas seçóes. Na primeira, mostrou-se a relaçăo do desenvolvimento das tecnologias de informaçấo e da comunicaçăo (TIC), realizando diálogo com o direito à privacidade e também com a compreensâo de princípio como elemento instituidor da regra. A segunda versa a respeito do tratamento do tema no cenário internacional e no Brasil, delineando aspectos coerentes no ordenamento brasileiro em comparaçăo a outros países, especialmente da Europa. Utilizou-se como metodologia a ontologia hermenêutica, adotando a fenomenologia hermenêutica a fim de compreender a realidade e a temática proposta. Os métodos de procedimento foram o monográfico e o histórico. 


\section{DIREITO FUNDAMENTAL DA PRIVACIDADE NA SOCIEDADE INFORMACIONAL: UMA COERÊNCIA NECESSÁRIA}

O desenvolvimento das tecnologias nos campos da informaçấo e da comunicaçăo, sobretudo a Internet, produziu reflexos sobre os conceitos de tempo e espaço, provocando uma série de alteraçôes nas formas de relacionamento interpessoais, seja na esfera pública ou privada. As Tecnologias de Informaçăo e Comunicaçăo (TIC) podem ser entendidas como mecanismos de valor ao estabelecer conexóes entre a sociedade civil e o Estado, mas a utilizaçăo inadequada das TIC tem potencial de infringir direitos sensíveis, tanto pelo Estado quanto por particulares. Nesse sentido, presencia-se uma sociedade em evoluçấo, ou uma sociedade da informaçấo, com um modelo de desenvolvimento sociopolítico na busca pela satisfaçăo das necessidades dos cidadáos e pela disseminaçăo do conhecimento (BATTEZINI; REGINATO, 2016, p. 6).

A sociedade informacional, termo preconizado por Manuel Castells, sociólogo espanhol, consiste em uma terminologia que tenta estabelecer um paralelo entre indústria e industrial. Uma sociedade industrial (conceito comum na tradiçăo sociológica) nâo é apenas uma sociedade em que há indústrias, mas uma sociedade em que as formas sociais e tecnológicas de organizaçâo industrial permeiam todas as esferas de atividade, começando com as atividades predominantes localizadas no sistema econômico e na tecnologia militar e alcançando os objetos e hábitos da vida cotidiana. Assim, o emprego dos termos "sociedade informacional" e "economia informacional" tenta uma caracterizaçâo mais precisa das transformaçóes atuais, além da sensata observaçâo de que a informaçâo e os conhecimentos sâo importantes para as sociedades. Porém, o conteúdo real de "sociedade informacional" tem que ser determinado pela observaçấo e pela análise (CASTELLS, 2008, p. 65).

Nesse sentido, a partir do termo cunhado por Castells, quando mal utilizados os instrumentos disponibilizados pelas TIC aliado ao incorreto armazenamento de dados abre-se o leque para devastar com a privacidade do indivíduo. No contexto contemporâneo em que dados sâo veiculados de maneira instantânea, o cidadăo, titular de seus dados, muitas vezes, perde o controle das informaçóes a seu respeito, inclusive as mais íntimas. Nesse cenário de mudanças paradigmáticas, constata-se a evoluçáo do direito à privacidade, o qual somente incorporou-se ao ordenamento jurídico brasileiro após ter conquistado reconhecimento no plano internacional. Dentro desse plano, é possível prescrever que o marco doutrinário ocorreu em 1890, nos Estados Unidos, quando Samuel Dennis Warren e Louis Demitz Brandeis publicaram artigo na Harvard Law Review, intitulado Right to privacy. Destaca-se que o direito à privacidade obteve reconhecimento na Declaraçăo Universal dos Direitos do Homem, em 1948, e, em 1966, ganhou regulaçáo pelo Pacto Internacional de Direitos Civis e Políticos. A previsăo legal desse direito na Convençâo Americana sobre Direitos Humanos aconteceu em 1969 (VIEIRA, 2007).

Dentro desse ângulo, a informaçăo, atualmente, pode ser considerada a base da vida e das relaçóes humanas e sociais. Isto porque quem possui o poder de comunicá -la, em regra, possui o poder de controle dos cidadáos, que tomarâo decisóes a partir do que conhecem (RAMINELLI; OLIVEIRA, 2015. p. 23). Na análise de Brenton (1992, p. 24), este lançou măo da comunicaçăo e do considerava o seu principal elemento, a informaçáo, como o elo fundamental entre a humanidade. A tecnologia permuta a 
livre informaçăo e isso é comunicaçăo, o fenômeno central de uma sociedade sem entropias. Logo, nessa perspectiva, uma sociedade em que uma comunicaçáo se realiza de forma livre e descentralizada, pode, na mesma medida, propiciar que a difusâo da informaçăo ocorra de igual forma.

No mesmo propósito, a revoluçáo tecnológica provoca uma mudança visceral no mundo hodierno, no caso de sua manifestaçăo mais inquietante, a Internet inova nos parâmetros de sua própria análise, na dimensăo formal do seu objeto, isto é, a virtualidade (PIMENTA, 2013, p. 14). As novas tecnologias, ou tecnologias digitais, expandiram enormemente a possibilidade de acesso à informaçăo e às formas de comunicaçâo, daí porque migraram de tecnologias de informática para serem nominadas Novas Tecnologias da Informaçấo e Comunicaçăo (NTICs). O desenvolvimento do que sâo comumente denominadas na literatura como novas tecnologias da informaçâo e da comunicaçăo foi propulsor de mudanças que afetaram a sociedade mundial em todos os seus aspectos (PIMENTA, 2013, p. 01).

Assim, modernamente, graças às novas tecnologias, o ser humano alcançou um desenvolvimento capaz de alterar a sua própria história. A tecnologia alcançou patamares que há décadas năo se pensaria fosse possível (NUNES; PATUSSI, 2016, p. 135). 0 acesso ao conhecimento a essas novas tecnologias torna-se competitivo e alguns Estados o tratam como impreterível ao desenvolvimento. Portanto, é imprescindível dar novos suportes de fixaçâo de conteúdos, e que a lei acompanhe esse desenvolvimento modificando os antigos parâmetros de proteçăo para contemplar novas abrangências de proteçăo que antes eram impensáveis (NUNES; PATUSSI, 2016, p. 136).

Logo, o Brasil, com a Constituiçâo Federal de 1988, consagrou o Princípio da Dignidade Humana (art. 1, III), protegendo os direitos de personalidade e reconheceu a inviolabilidade da vida privada, da intimidade e da honra das pessoas (art. 5, X). Apesar de a Constituiçáo ter assegurado a tutela da privacidade náo se pode olvidar que, conforme leciona Streck (2006), as condiçôes de possibilidade para que o intérprete possa compreender um texto implicam a existência de uma pré-compreensâo acerca da totalidade do sistema jurídico-político-social. Nesse sentido, uma "baixa compreensâo" a respeito do sentido da Constituiçâao na seara do Estado Democrático e de Direito acarretará uma "baixa aplicaçâo", com efetivo prejuízo para a concretizaçáo de direitos fundamentais. Entende-se oportuno destacar explicaçăo de Streck (2006, pp. 51-54) a respeito de năo existir etapas distintas na compreensăo.

Compreender é aplicar. Filosoficamente, ao menos depois da invasăo da filosofia pela linguagem, năo é possível separar interpretaçăo e aplicaçăo. O sentido năo se desloca do âmbito da compreensăo. Aqui parece năo ter sido compreendido bem a tese (central) gadameriana da applicatio, pela qual interpretar é aplicar, que sempre aplicamos, que năo interpretamos por parte ou etapas e que, enfim, "em toda a leitura tem lugar uma aplicaçáo" (Gadamer). Quando Gadamer diz isso, ele náo está se referindo à aplicaçâo da lei ou na aplicaçâo judicial. [...] Aplicaçăo (applicatio) é a síntese hermenêutica da compreensấ; a aplicaçăo de que fala Gadamer năo é uma fase posterior da interpretaçấo ou compreensáo.

Na mesma linha, coaduna-se com Isaia (2011, p. 82) de que "a interpretaçăo de um texto se desvelaria desde a sua assumida funçăo como mediador de um nexo histórico 
mais amplo, completo na perspectiva da história universal". Assim, resta evidenciado que a experiência humana tem significado por ser histórica e seguir uma unidade coerente na linha do tempo. Como bem explica Isaia (2012, p. 171), a partir de Dworkin, "os sentidos se dăo no distanciamento sujeito-objeto e năo na intersubjetividade, através da linguagem".

Reitera-se que o direito à privacidade e a sua coerente tutela tem previsăo constitucional, mas a Constituiçâo, que deveria ser o local para a obtençăo de respostas concretizadoras, foi alterada em um "texto aberto". No Brasil, a interpretaçâo da Constituiçâo acontece dentro de uma tradiçâo liberal-individualista que ainda conforma o sentidocomum-teórico dos juristas (WARAT, 1995). Desse modo, quando o "operador do direito" (sic) fala o (ou sobre) o Direito, fala a partir do seu "desde-já-sempre-sabido" sobre, e o "como-sempre-tem-sido" o Direito (STRECK, 2000, p. 268). Consequentemente, os direitos sociais, característicos do constitucionalismo contemporâneo, săo relegados a um segundo plano pelos juristas com base na consideraçăo de que somente os direitos individuais de liberdade seriam prontamente exigíveis.

Dentro dessa lógica liberal, muitas vezes, a applicatio tem ocorrido em etapas posteriores à interpretaçăo ou compreensăo, realizando, apenas a adequaçáo da norma ao caso concreto. Porém, conforme bem alerta Streck (2010, p. 226), "quando me deparo com o texto, ele já ex-surge normado" e, assim, a interpretaçăo de um texto jurídico nâo se desvincula da antecipaçâo de sentido pelo intérprete. Nessa mesma linha, ao rechaçar diferenciaçăo entre conhecer, interpretar e aplicar Dworkin (1999, p. 72) entende que os princípios săo standards que devem ser observados por refletirem uma exigência de justiça ou alguma outra dimensăo de moralidade, o que os distingue das normas.

Nesse sentido, Oliveira (2008) observa que Dworkin destaca a diferença qualitativa entre regras e princípios, mas ambos săo tratados como conjunto de padrôes que apontam para decisōes, tendo distinçôes quanto à natureza de orientaçăo. As regras sâo aplicáveis tudo ou nada, ou seja, "quando se argumenta com uma regra ela é ou nâo é". Já num argumento de princípio, é necessário se mostrar como sua aplicaçăo mantém uma coerência com o contexto global dos princípios (dimensăo de peso). Assim, a aplicaçăo de um princípio náo pode significar a exclusáo de outros.

Dworkin entende que o Direito sempre proporciona uma boa resposta, tendo em vista que o juiz ao julgar escreve a continuidade de uma história e, para exemplificar essa similaridade do Direito com a narrativa, utiliza a metáfora do "Romance em Cadeia". Nessa metáfora elaborada do Dworkin cada juiz deve se considerar parte de um complexo empreendimento em cadeia, ao lançar-se à criaçăo e à interpretaçâo jurisprudenciais. Concebe a interpretaçâo jurídica como a extensâo de uma história institucional do Direito, que se desenvolve a partir de decisóes, estruturas, convençóes e práticas (OLIVEIRA, 2008).

Desse modo, o processo interpretativo seria como um romance em cadeia que năo é escrito somente por um autor, mas vários; cada um é responsável pela redaçâo de um capítulo separado, devendo continuar a elaboraçăo a partir de onde seu antecessor parou. Nesse contexto, destaca-se a integridade, ou seja, na complexidade da tarefa a que estaria submetido cada escritor ao redigir o romance ele deve escrever cada capítulo de modo a criar da melhor maneira possível o romance com a complexidade 
da tarefa enfrentada pelo juiz que, ao decidir um caso difícil, teria a funçăo de dar continuidade à história.

De acordo com a teoria de Dworkin (2003) da integridade do Direito existe um valor moral no respeito à integridade e à coerência de um sistema jurídico e, desse modo, torna-se premente o imperativo de o Direito sustentar concepçăo coerente que seja o reflexo dos valores da comunidade política. Assim, conforme a noçăo de fidelidade a um sistema de princípios cada cidadăo possui a responsabilidade de se manter leal ao sistema de princípios e valores da comunidade a qual pertence (DWORKIN, 2003).

Oportuno ressaltar que Streck discorda de Dworkin, quando esse afirma que as regras sâo aplicáveis à maneira do tudo ou nada e que os princípios, por sua vez, enunciariam uma razấo que conduz o argumento em certa direçăo. Concorda-se com Streck (2006, p. 170) no sentido que a regra năo subsiste sem o princípio e, do mesmo modo, năo há princípio que possa ser aplicado sem o "atravessamento" de uma regra. Nesse contexto, é imperativo o uso de princípios a fim de encontrar a resposta acertada, aquela que decorre de uma correta interpretaçâo à luz da hermenêutica à soluçáo dos conflitos. E, para chegar a esta resposta acertada, é indispensável uma interpretaçâo correta, no plano de uma argumentaçăo racional. Assim, conforme preconiza Lenio Streck (2006, p. 145) os princípios ${ }^{5}$ têm a finalidade de impedir múltiplas respostas e, sendo assim, fecham a interpretaçăo.

É através dos princípios - compreendidos evidentemente da superaçăo dos discursos fundacionais acerca da interpretaçáo jurídica - se torna possível sustentar a existência de respostas adequadas (corretas para cada caso concreto). Portanto, a resposta dada através dos princípios é um problema hermenêutico (compreensăo), e năo analítico-procedimental (fundamentaçăo).

Feito esse recorte a respeito da compreensăo de princípio, qual seja, como elemento instituidor da regra, passa-se a dissertar sobre o desenvolvimento de uma noçăo de privacidade, destacando que náo ocorre processo subsuntivo ao interpretar um texto com base na Constituiçaáo, pois "ao vislumbrar o texto, já há um ver-prévio e um préconceito acerca da Constituiçăo" (STRECK, 2006, p. 175).

O desenrolar da noçáo de privacidade aconteceu paralelo ao surgimento da própria possibilidade material de assegurar esse direito. 0 nascimento do direito à privacidade, conforme leciona Rodotà (2008, p. 26), pode ser historicamente relacionado à desagregaçấo da sociedade feudal em que o isolamento era privilégio de eleitos ou de outras pessoas as quais, por necessidade ou opçâo, viviam distantes da comunidade.

Nessa conjuntura de consolidaçăo do direito à privacidade e da regulaçăo da rede, destacam-se as contribuiçōes de Pérez Luño e Stefano Rodotà. A Carta Magna faz distinçâo entre os institutos da intimidade e da privacidade, pois no art. $5^{\circ}, \mathrm{X}$, aponta que "săo invioláveis a intimidade, a vida privada, a honra e imagem das pessoas, assegurado o direito a indenizaçâo por dano mora ou material decorrente de sua violaçấo" (BRASIL, 1988), desse modo se verifica que existe uma cisăo da intimidade e de outras manifestaçōes de privacidade.

Conforme o autor antes de estarem cindidos, há um acontecer que aproxima regra e princípio em duas dimensôes, a partir de uma anterioridade, isto é, a condiçâo de possibilidade da interpretaçấo da regra é a existência do princípio instituidor (STRECK, 2006, p. 167). 
Apesar dessa aparente separaçáo, na Constituiçăo Federal, dos direitos à intimidade e à privacidade, coaduna-se com entendimentos Stefano Rodotà, que reivindica a autonomia do individuo na sociedade de informacional e sugere um novo conceito de privacidade, qual seja, da definiçăo histórica do "direito de ser deixado só" para o "direito à autodeterminaçăo informativa". Esse conceito abarca o direito de manter o controle sobre as próprias informaçóes; o direito de escolher aquilo que será revelado; direito ao esquecimento, em suma, o direito de determinar a maneira de construir a própria esfera particular.

Ao apresentar uma nova percepçăo da privacidade, Rodotà (2008) afirma que esse direito tem a ver com a proteçăo da personalidade, năo da propriedade. Assim, a ressignificaçăo da privacidade, comodireitoà autodeterminaçăoinformativa, colabora para uma concepçăo integral da pessoa, possibilitando o livre desenvolvimento da personalidade. Desse modo, a garantia da privacidade como direito fundamental, pressupóe um ordenamento jurídico cujos regramentos sejam interpretados em consonância à pessoa humana. Nesse sentido, sublinha-se entendimento de Rodotà (2008, p. 24).

[...] cada vez mais frágil a definiçăo de "privacidade" como o "direito a ser deixado só", que decai em prol de definiçóes cujo centro de gravidade é representado pela possibilidade de cada um controlar o uso das informaçôes que lhe diz respeito. Náo que esse último aspecto estivesse ausente das definiçōes tradicionais: nelas, porém, ele servia muito mais para sublinhar e exaltar o ângulo individualista, apresentando a privacidade como mero instrumento para realizar a finalidade de ser deixado só; enquanto hoje chama a atençăo, sobretudo, para a possibilidade de indivíduos e grupos controlarem o exercício dos poderes baseados na disponibilizaçăo de informaçóes, concorrendo assim para estabelecer equilíbrios sociopolíticos mais adequados.

Essa fragilidade na conceituaçăo de privacidade como "direito a ser deixado só" resta evidenciada, especialmente, na sociedade informacional, na qual tanto as estruturas públicas como as empresas privadas realizam coleta de dados pessoais dos indivíduos. Ao se abordar a temática proposta, torna-se imperioso assinalar que alguns doutrinadores entendem ter a privacidade maior abrangência do que a intimidade. Nesse sentido, Moraes (2002, p. 80) afirma que "os conceitos constitucionais de intimidade e vida privada apresentam grande interligaçăo, podendo, porém, ser diferenciados por meio da menor amplitude do primeiro que se encontra no âmbito de incidência segundo".

Na mesma linha de Rodotá (2008), Pérez Luno (2005) assinala que os direitos fundamentais devem ser compreendidos a partir de percepçóes que năo realizam a divisâo de seus conteúdos em âmbitos apartados. Desse modo, o que se tutela é a intimidade a partir da qual os demais direitos seriam tutelados, inclusive os direitos à honra e à imagem. Compreende-se que essa concepçăo unitária é a mais adequada, especialmente na sociedade informacional, pois relaciona os direitos fundamentais à autonomia do titular, detentor do direito à autodeterminaçáo informacional. Esse direito, por sua vez, corresponde, segundo Sarmento (2004, p. 204) ao direito de o indivíduo determinar o seu destino, como casar-se ou năo, ter filhos ou năo, expor em público sua própria imagem, voz e honra pessoal e demais direitos nessa mesma linha, desde que nâo afetem direitos de terceiros, nem a lei moral, nem a ordem constitucional. 
É premente, argumenta Pérez Luño (2005), a necessidade de transpor as concepçôes que serviram de base para o Estado Liberal, quando bastava a postura negativa pelo Estado para garantir a satisfaçăo dos direitos fundamentais dos cidadăos. O caráter negativo dos direitos fundamentais relaciona-se com a teoria liberal do Estado de Direito burguês, defendido por Carl Schmidtt, na qual o Estado deve respeitar a esfera jurídica do cidadâo, năo assumindo, entretanto, nenhum dever para realizaçăo das liberdades públicas. Essa teoria foi superada pela teoria do Estado Social, que enfatiza o caráter positivo dos direitos fundamentais, ao demonstrar que, para se atingir a liberdade real, em contraposiçâao à liberdade meramente jurídica, impóe-se uma serie de prestaçóes estatais (VIEIRA, 2007, p. 96).

Destaca-se que a teoria do Estado Social superou a visăo restritiva dos direitos fundamentais, ressaltando, conforme explica Vieira (2007), a teoria institucional dos direitos fundamentais, segunda a qual, os direitos fundamentais, para serem efetivos, precisam ser protegidos institucionalmente e enriquecidos por atos normativos que lhes ofereçam direçăo, conteúdo e funçăo.

Verifica-se que a tutela do direito à privacidade demanda uma atuaçáo positiva do poder público para assegurar a nâo intromissâo de terceiros na privacidade alheia. O posicionamento ativo do Estado torna-se ainda mais essencial ao compreender os direitos fundamentais na dimensâo social. Assim, resta evidenciada o imperativo do reconhecimento do controle de fluxo informacional pelo próprio indivíduo. Ao entender que direito à privacidade deve ser compreendido de maneira integrada às diretrizes internacionais, insta destacar a distinçâo entre intimidade e privacidade realizada pela doutrina alemă, a qual distingue a privacidade em três círculos concêntricos. Nesse sentido, frisa-se a explicaçấo de Vieira a respeito da teoria das esferas (2007, p. 37):

[...] O primeiro círculo e de maior amplitude representa a esfera privada, excluindose do conhecimento de terceiros aspectos específicos da vida da pessoa. O segundo compreende os valores atinentes ao âmbito da intimidade ou esfera confidencial, cujo acesso é mais restrito, somente permitido àqueles indivíduos com os quais a relaçâo pessoal se desenvolve de forma mais intensa. 0 terceiro e mais fechado dos círculos abrange a reserva, o sigilo, o segredo, as mais profundas manifestaçóes espirituais da pessoa, caracterizadoras da vida íntima stricto sensu.

Percebe-se que essa teoria, adotada pelo Tribunal Federal Constitucional Alemăo6 no caso da Lei do Microcenso, realiza diferenciaçăo entre intimidade, vida privada e segredo, apesar de ser questionável a possibilidade de delimitar os limites que balizam as três esferas. A par da teoria das esferas houve a formulaçăo da teoria do mosaico, em que a partir de coletânea de dados é possível traçar o perfil do cidadăo, por Fulgêncio Conessa. ${ }^{7}$ Aliás, Canotilho (2003) conceitua direito à privacidade como

$6 \quad$ Em 16 de julho de 1960, o Tribunal Alemăo afirmou que o terceiro e mais fechado dos círculos nâo pode ser violado pelo Estado nem mesmo por lei, por ser tal âmbito um recinto inatingível da vida privada, que náo pode ser submetido a qualquer açâo do poder público. [...] De outro lado, as informaçôes solicitadas pelos órgáos públicos, que exorbitem essa esfera e que náo violem a dignidade ou a autodeterminaçăo do individuo, devem ser prestadas ao Estado para pesquisas estatísticas, por exemplo. No caso em exame, o Tribunal considerou que a Lei de Microcenso năo viola a esfera do segredo confirmando a constitucionalidade do ato normativo (VIEIRA, 2007, p. 39).

7 Dados pessoais assemelham-se a pequeninas pedras que formam um mosaico, ou seja, vistas por si sós nada representam, mas, uma vez unidas, formam um conjunto pleno de significado que, nesse caso, compóem a personalidade do indivíduo. MIGUEL, Carlos Ruiz. Em torno de la protección de lós datos 
direito de personalidade. O constitucionalista português faz distinçăo ${ }^{8}$ entre direitos de personalidade e direitos fundamentais. ${ }^{9}$ Segundo o constitucionalista português, os direitos de personalidade abrangem os direitos de estado (direito de cidadania), os direitos distintivos da personalidade (direito à identidade pessoal, direito à informática) e os direitos sobre a própria vida.

Segundo a teoria do mosaico, é irrelevante o fato de a informaçăo do indivíduo pertencer à esfera da intimidade, vida privada do segredo, pois interessa, sobretudo, é a utilizaçâo que se fará com tal dado informacional. Assim, há dados que possuem aparência de inofensivos à violaçâo, porém, quando colacionados com outros dados, apresentam risco à violaçáo da privacidade do cidadáo. Destaca-se que a teoria do mosaico colabora para o entendimento da problemática relacionada à coleta e ao armazenamento de dados pessoais tanto por entes públicos quanto por privados, em especial na sociedade informacional na qual é possível realizar, em instantes, a interligaçâo de dados e delinear o perfil de indivíduos.

Percebe-se que o discurso sobre a privacidade aparece como um discurso sobre dados pessoais e, portanto, sobre a informaçăo. Porém, alerta-se que considerar a relevância da informaçăo como um dado somente dos tempos atuais é abstrair a sua importância em períodos anteriores. Reconhece-se que, nos dias atuais, há maior desenvoltura na manipulaçâo, coleta, tratamento e comunicaçăo da informaçăo e, concomitantemente, aumentam as formas com as quais as informaçóes podem utilizadas, coadunando com a observaçáo de Rodotà (2008) no sentido de que a novidade fundamental introduzida pelos computadores é a transformaçăo de informaçăo dispersa em informaçăo organizada.

Pode-se afirmar que, de fato, na sociedade informacional, a Internet alavancou o acesso às informaçóes e possibilitou a troca de dados, em diferentes formatos, entre pessoas e organizaçôes. No entanto, náo se pode negar que é a organizaçâo das empresas e também do poder público em rede alavancou a invasăo da vida privada de clientes e dos cidadáos em busca de dados pessoais. Assim, a Internet se constitui em ameaça à privacidade dos indivíduos, pois facilita a troca de informaçôes entre os prestadores de serviços (público ou privado), além de facilitar o monitoramento das condutas virtuais dos usuários da rede.

Salienta-se que o uso generalizado do mecanismo de interconexăo de informaçôes pessoais armazenadas em bancos de dados públicos tem gerado preocupaçôes em relaçóes ao direito à privacidade em razăo da violaçăo da autodeterminaçăo dos indivíduos pelo monitoramento estatal. Há, conforme alerta Rifkin (2001, p. 82), desequilíbrio informacional na relaçăo do internauta em face do fornecedor, tendo em vista que esse ao operar e dominar o ciberespaço detém, evidentemente, informaçóes em maior volume e, assim, mais controle e poder.

$\underline{\text { nota } 8}$

personales automatizados. Revista de Estudios Políticos. Madrid, n. 84, pp. 242-243, abril/junho. 1994 apud BESSA, Leonardo Roscoe. Săo Paulo: Revista dos Tribunais, 2003, p. 91.

$8 \quad \mathrm{O}$ autor reconhece que, em razăo da interdependência entre o estatuto positivo e o estatuto negativo do cidadáo, e em face da concepçáo de um direito geral de personalidade como direito à pessoa ser e à pessoa devir, cada vez mais os direitos fundamentais tendem a ser direitos de personalidade e vice-versa (CANOTILHO, 2003, p. 396).

9 Direitos fundamentais sâo os direitos do homem, jurídico-institucionalmente garantidos e limitados espaço-temporalmente (CANOTILHO, 2003, p. 392). 
Delineados aspectos do direito à privacidade, examina-se, na próxima seçăo, a proteçáo de dados na sociedade informacional, expondo espécies de dados pessoais e o panorama internacional da tutela desses dados. Posteriormente, destacam-se aspectos do anteprojeto de lei de dados pessoais no Brasil, que foi submetido, pelo Poder Executivo Federal, para consulta pública (http://participacao.mj.gov.br/dadospessoais/).

\section{A PROTEÇÃO DE DADOS PESSOAIS: O TRATAMENTO DO TEMA NO CENÁRIO INTERNACIONAL E NO BRASIL}

A realidade virtual facilitou o acesso a informaçôes, possibilitando uma nova faceta da democracia, mas, ao mesmo tempo, o que está por trás de um dado é uma pessoa e, assim, os dados pessoais devem ser tratados com a devida garantia e proteçâo. A necessidade de proteger o indivíduo do risco de divulgaçăo de seus dados tem origem, conforme ensina Limberger (2007, p. 58), no fato de que possuem um conteúdo econômico pela possibilidade de sua comercializaçăo e há a possibilidade de toda uma serie de empregos secundários dos dados recolhidos, os quais nem sempre foram consentidos.

Na sociedade informacional, a interconexăo de arquivos dos usuários com intuito de formaçâo de bancos de dados, construídos, grande parte das vezes, com informaçôes dos cidadăos sem o seu aval, impulsionou a concepçâo e criaçăo de mecanismos de proteçáo aos dados pessoais. Inclusive, a relevância da temática reflete-se em documentos internacionais, especialmente na Carta de Direitos Fundamentais da Comunidade Europeia que reconhece a proteçâo de dados como um direito fundamental autônomo e, como bem destaca Rodotà (2008, p. 19) “a inviolabilidade da pessoa deve ser reconfigurada e reforçada na dimensâo eletrônica. Devem ser rejeitadas todas as formas de reducionismo".

Desse modo, no sentido do apregoado por Dworkin, os princípios, inclusive da proteçấo de dados, devem ser respeitados por refletirem uma exigência de justiça. No tocante à tutela de dados pessoais, as iniciativas legislativas surgiram em 1970. A Lei do Land alemáo de Hesse, de 1970;10 a lei nacional de proteçăo de dados da Suécia: o Estatuto para bancos de dados de 1973 - Datalaf 289,11 além do Privacy Act norte-americano, de 1974. Conforme Sampaio (1998), essa primeira geraçăo de leis que previa a concessáo de autorizaçôes para a criaçâo de bancos de dados e do posterior controle por órgăos públicos, permaneceu até a lei federal da República Federativa da Alemanha sobre proteçấo de dados pessoais, de 1977.

Conforme registra Doneda (2006), a Alemanha, a partir dessa legislaçăo, pretendia concluir a realizaçăo de um censo em que comparava os dados pessoais fornecidos com

10 Essa lei criou uma autoridade - Comissário para proteçâo de dados - para controlar a elaboraçâo informática de dados pessoais no confronto com a administraçâo pública, em iniciativa pioneira na Europa.

11 Em 1976, o parlamento sueco promulgou uma lei de acesso a registros públicos e aos atos oficiais do governo. No tocante à Datalag, a Suécia estudava desde 1963 a ligaçáo de bancos de dados como o registro civil, de veículos, de propriedade imobiliária, policiais, serviços sociais e empregatícios no seu Escritório Central de Estatística. A tentativa de implementar um Registro Total da Populaçáo de um Registro Central de Contribuintes provocou uma reaçăo contrária da sociedade, motivando a promulgaçáo da primeira lei mundial de proteçâo de dados pessoais (BENNET, C. Regulating privacy, Ithaca: Cornell University Press, 1992, p. 47). 
os do registro civil. Esse censo gerou controvérsias, pois havia possibilidade de envio às autoridades pessoais dos dados colhidos, bem como a previsâo de multa a quem se recusasse a responder aos questionamentos.

Na década de 1990, a Uniăo Europeia aprovou sua diretiva 95/46/CE ${ }^{12}$ sobre a "proteçăo das pessoas singulares no que diz respeito ao tratamento de dados pessoais e à livre circulaçăo desses dados". A Diretiva tinha como objetivo uniformizar as normas de tratamento de dados pessoais no âmbito da Uniăo Europeia, procurando ao mesmo tempo proporcionar um nível mínimo de proteçâo aos dados pessoais, bem como fomentar e fortalecer o mercado interno europeu com a adoçâo de um padrăo comum a todos os Países-membros.

Feito esse resgate histórico a respeito das geraçôes de leis atinentes à proteçâo de dados, percebe-se que o Brasil demorou a apresentar, juridicamente, legislaçăo para tutelar esse direito. Com base nos ensinamentos de Dworkin, há um valor moral na obediência à coerência de um sistema jurídico, tornando-se imprescindível de o ordenamento brasileiro assegurar concepçâo integrada da proteçâo de dados pessoais Cabe explicar, neste momento, que o sentido é dado pelos intérpretes e năo estăo nos textos legais, pois, no Estado Democrático de direito, como leciona Isaia (2012, p. 169), “o direito assume um novo papel representado pela relaçăo entre jurisdiçâo e legislaçâo".

Em relaçâo à situaçâo da tutela de dados pessoais no Brasil, registra-se que o ordenamento jurídico estabelece, de forma indireta, essa proteçấo. A Constituiçâo prevê a inviolabilidade da vida privada e regula o habeas data para garantir o conhecimento e a correçăo de informaçóes relativas ao impetrante. Mas, somente na década de 2000, passou a se delinear a discussâo legislativa a respeito da tutela, de forma direta, dos dados pessoais.

O Poder Executivo Federal submeteu à consulta pública anteprojeto de lei sobre a temática. $O$ texto do anteprojeto, após debate público promovido pelo Ministério da Justiça em parceria com Observatório Brasileiro de Políticas Digitais do Comitê Gestor da Internet no Brasil, foi consolidado em um texto final, o qual está disponibilizado em meio virtual para comentários dos cidadăos (BRASIL, 2015).

No Brasil, há o Código do Consumidor de 1990 que versa sobre os bancos de dados nas relaçōes de consumo e legislaçâo complementar, autorizando quebra de sigilo bancário, em situaçōes excepcionais, sem autorizaçăo judicial. Porém, inexiste legislaçăo específica da tutela dos dados pessoais e, conforme assinala Doneda (2006, p. 358), a tutela de dados pessoais possuiria um caráter instrumental, derivado da proteçâo da privacidade, mas seria limitada por essa. Conforme entrevista concedida por Daniel Doneda, um dos responsáveis pela elaboraçăo do anteprojeto, a lei tem por objetivo garantir direitos ao cidadáo sobre seus dados pessoais, além de determinar o modo de tratamento desses dados pela iniciativa privada e entidades públicas. Além disso, os dados pessoais devem ser tratados, pelas entidades públicas e privadas, sob o viés dos princípios da finalidade, transparência, segurança e responsabilidade.

12 Os Estados-membros poráo em vigor as disposiçóes legislativas, regulamentares e administrativas necessárias para dar cumprimento à presente diretiva o mais tardar três anos a contar da data da sua adoçăo In: UNIĀO EUROPEIA. Directiva 95/46/CE do Parlamento Europeu e do Conselho da Europa. 
Dividido em 13 eixos temáticos, ${ }^{13}$ o anteprojeto estabelece o tratamento de dados pessoais para proteger a personalidade e a dignidade da pessoa natural. Destaca-se que, entre os princípios de proteçáo de dados, por exemplo, estăo os da transparência e do livre acesso, pelos quais os titulares sempre devem ter conhecimento quando for realizado um tratamento de dados a seu respeito; e o princípio da nâo-discriminaçăo no sentido de que a proteçăo de dados năo seja compreendido somente na perspectiva da privacidade individual, mas que leve em consideraçăo o fato que a utilizaçăo de dados pessoais năo possa facilitar práticas discriminatórias.

Em relaçâo aos princípios de tutela de dados, entende-se que eles - como instituidores da regra (STRECK, 2014) - devem ser compatíveis e coerentes com as legislaçôes de outros países. Entende-se como avanço legislativo o anteprojeto estipular já no artigo inicial a proteçáo dos direitos fundamentais da liberdade e privacidade, dispositivo corolário ao art. 5 da Constituiçăo Federal de 1988. Assim, pode-se afirmar que há traços da integridade tal como definida por Dworkin (2003, p. 229), que contribuem à eficiência do direito "pois se as pessoas aceitam que sâo governadas năo apenas por regras explícitas, mas por quaisquer regras que decorrem dos princípios que essas decisōes pressupóem, entăo o conjunto de normas públicas reconhecidas pode expandirse e contrair-se organicamente".

A leitura atenta do anteprojeto revela que há mais de uma dezena de referências a "órgâo competente"; "órgâo competente estabelecerá"; "órgâo competente estimulará a adoçăo de padróes", no entanto náo há informaçóes atinentes à formaçăo e ao funcionamento deste órgâo regulador. Diferentemente do Brasil, na Europa, todos os países dispōem de entidades administrativas ${ }^{14}$ nos respectivos governos responsáveis pela aplicabilidade da Diretiva, apesar de serem variáveis as atribuiçóes desses setores de país para país, conforme explica Vieira (2007).

Percebe-se maior avanço da Uniâo Europeia no tocante à proteçáo de dados pessoais, mas cabe destacar que o tema tem sido discutido nos Estados Unidos desde a década de 1970. Conforme ensina Sampaio (1998), já em 1975 houve publicaçăo de ato normativo com intuito de proteger a privacidade dos indivíduos no que diz respeito ao tratamento de suas informaçōes pelas agências governamentais. Na América Latina, apenas Chile e Argentina já possuem leis específicas sobre proteçâo de dados pessoais. Registra-se que a aprovaçâo de atos normativos relacionados ao tema exige que os países atuem, de maneira coordenada, para, como assinala Vieira (2007), nâo seja obstruída a transmissâo de dados pessoais. Inclusive, nesse sentido, a Organizaçăo dos Estados Americanos cunhou a Convençāo Americana sobre Autodeterminaçâo Informativa, destacando que a tutela de proteçáo de dados pessoais deve apresentar coerência em razăo do caráter transnacional da Internet e do fluxo transfronteiriço das informaçôes.

13 Eixos temáticos: escopo e aplicaçâo; dados pessoais, dados anônimos e dados sensíveis; princípios; consentimento; término do tratamento; direitos do titular; comunicaçâo, interconexăo e uso compartilhado de dados; transferência internacional de dados; responsabilidade dos agentes; segurança e sigilo de dados pessoais; boas práticas; como assegurar estes direitos, garantias e deveres e disposiçôes transitórias (BRASIL, 2015).

14 a) controlar e fiscalizar o cumprimento das disposiçôes legais e regulamentares em matéria de proteçâo de dados pessoais; b) exercer poder de autoridade, quer ordenando o bloqueio, quer o apagamento ou destruiçáo de dados, quer proibindo temporária ou definitivamente o tratamento de dados pessoais; c) advertir ou censurar publicamente o responsável pelo tratamento de dados pessoais, pelo náo cumprimento das disposiçōes legais (UNIAO EUROPEIA. Directiva 95/46) 
Pode-se afirmar que, gradativamente, os países têm percebido os riscos advindos da tecnologia informacional e a necessidade da tutela do direito à privacidade. Nesse cenário, nota-se a adoçấo de estratégia integrada na proteçâo de dados. Mas, conforme ensina Rodotà (2008, p. 84), "năo há soluçôes simples e existe a necessidade de um enfoque global".

\section{CONSIDERAÇÕES FINAIS}

O desenvolvimento da humanidade sempre esteve adstrito ao conhecimento e a exasperaçáo do mesmo, a utilizaçâo desse recurso foi primordial durante a Revoluçăo Industrial, sendo que as máquinas e a expertise tecnológica da época auxiliaram de forma potencial na estruturaçăo da sociedade e modernizaçâo na forma de produçâo de bens materiais e dos serviços prestados. Hodiernamente, vivencia-se uma nova perspectiva, calcada na informaçăo, haja vista que esse recurso foi modificado, tendose edificado como um ativo econômico, sendo apropriado por empresas, instituiçôes, naçôes e Estados.

Esse quadro de desenvolvimento tecnológico e evoluçăo proporcionou a solidificaçăo da sociedade da informaçăo, onde as conexóes realizadas através das Tecnologias da Informaçăo e Comunicaçăo (TIC), tendo como suporte a Internet, promoveu a difusâo célere e dinâmica dessa informaçâo. Esta comunicaçâo cheia de signos de conteúdo é primordial ao progresso social, econômico e também jurídico. E nesse ponto, que se visualiza a extrema necessidade de rever antigos parâmetros de proteçâo dos indivíduos e dos atores sociais, de modo a contemplar novas abrangências de vigilância, regulaçăo e resguardo, para meandros que antes eram impensáveis, como a proteçấo de dados pessoais.

Em razăo do exposto na construçăo deste artigo, percebe-se que a elaboraçáo de uma legislaçáo coerente, na maior parte dos aspectos ao panorama internacional, evidencia o compromisso do Brasil, país regido por uma Constituiçấo dirigente, na defesa dos dados pessoais. Reitera-se que garantias relacionadas à privacidade passam a ser compreendidas numa perspectiva mais abrangente, abarcando, ainda, as formas de controle viabilizadas com a manipulaçâo de dados pessoais. Para tanto, as estratégias de tutela exigem a integraçáo de diversos instrumentos e a atuaçăo dos poderes governamentais a partir do pressuposto de que, conforme ressalta Isaia (2012, p. 170), de que "os direitos e deveres legais foram criados pela própria comunidade".

A reflexăo sobre as vantagens e desvantagens das tecnologias revela a premência do reconhecimento do direito à autodeterminaçăo informativa. Entende-se, com base em Rodotà, a necessidade de correspondência entre o nível de proteçáo desejado e o nível de proteçáo efetivo e isso requer parcela de privacidade, garantida por regras. O cotejo do tratamento do tema no Brasil e no cenário internacional apontou que o país está iniciando a trajetória na consolidaçăo de direitos a fim de assegurar aos cidadâos o acesso às facilidades advindas das tecnologias da informaçăo e comunicaçăo e, concomitantemente, a garantia da tutela de seus direitos fundamentais. Nâo se pode negar que as formas tradicionais de proteçâo da privacidade sâo difíceis na sociedade informacional e, nesse contexto, torna-se imperativo a aplicaçăo de mecanismos integrados e que năo se resumam somente a regras nacionais. 


\section{REFERÊNCIAS}

BATTEZINI, Andy Portella; REGINATO, Karla Cristine. O Ativismo Popular e o Papel das Mídias Digitais: Reflexos de um Novo Modelo de exercer Democracia no Cenário Contemporâneo e seus impactos na esfera Política. In: Revista de Direito Brasileira, Sáo Paulo, v. 15, n. 6, pp. 173-184, set./dez. 2016. Disponível em: <http://www.rdb.org.br/ojs/ index.php/rdb/article/view/401>. Acesso em: 05 fev. 2017.

BENNETT, C. Regulating privacy, data protection and public policy in europe and the united states. Ithaca: Cornell University Press, 1992.

BRASIL. Constituiçáo Federal. Brasília: Senado Federal, 1988. Disponível em: <http:// www.planalto.gov.br/ccivil_03/Constituicao/Constituicao.htm>. Acesso em: 16 jun. 2015.

Ministério da Justiça. Disponível em: <http://participacao.mj.gov.br/dadospessoais/>. Acesso em: 10 jun. 2015.

BRENTON, Philip. A Utopia da Comunicaçăo. Lisboa: Instituto Piaget, 1992.

CASTELLS, Manuel. A Sociedade em rede. 6. ed. Traduçăo de Roneide Venancio Majer. Săo Paulo: Paz e Terra, 1999. v.1.

A Sociedade em rede. 11. ed. Traduzido por Roneide Venâncio Majer. Săo Paulo: Paz e Terra, 2008. v. 1.

A Galáxia da Internet: reflexóes sobre a internet, os negócios e a sociedade. Traduçăo de Maria Luiza X. de A. Borges. Rio de Janeiro: Zahar, 2003.

DONEDA, Daniel. Da privacidade à proteçăo de dados pessoais. Rio de Janeiro: Renovar, 2011.

DWORKIN, Ronald. Los derechos en serio. Barcelona: Ariel Derecho, 1999.

O império do direito. Traduzido por Jefferson Luiz Camargo. Săo Paulo: Martins Fontes, 2003.

Levando os direitos a sério. Traduzido por Nelson Boeira. 3. ed. Săo Paulo: WMF Martins Fontes, 2010.

ISAIA, Cristiano Becker. Processo civil, atuaçăo judicial e hermenêutica filosófica. $2^{\mathrm{a}}$ ed. Curitiba: Juruá, 2011.

Processo civil e hermenêutica: crise do procedimento ordinário e o redesenhar da jurisdiçâo processual civil pela sentença (democrática) liminar de mérito. Curitiba: Juruá, 2012.

LIMBERGER, Têmis. 0 direito à intimidade na era da informática. Porto Alegre: Livraria do Advogado, 2007.

NUNES, Luiz Felipe; PATUSSI, Marcio Assis. A Potencialidade do Desenvolvimento Tecnológico e sua relaçáo com o Homem. In: Revista Argumentum, Vitória, v. 8, n. 3, pp. 133-145, set. /dez. 2016. Disponível em: <http://www.periodicos.ufes.br/argumentum/ article/view/10284/10430〉. Acesso em: 08 fev. 2017. 
PIMENTA, Viviane Raposo. Novas Tecnologias da Informaçăo e Comunicaçăo e a Possibilidade de Acesso à Justiça. In: Revista de Direito Brasileira, Sáo Paulo, ano 3, v. 4, jan. /abril, 2013. Disponível em: <http://www.rdb.org.br/ojs/index.php/rdb/article/ view/24>. Acesso em: 05 fev. 2017.

PÉREZ LUN̂O. Derechos humanos, Estado de Derecho y Constitución. 9. ed. Madri: Editorial Tecnos, 2005.

RAMINELLI, Francieli Puntel; OLIVEIRA, Rafael Santos de. O Cosmopolitismo por uma Internacionalizaçâo do Direito: O Fortalecimento Recíproco do Global e do Nacional por meio da Proteçâo do Direito Humano à Informaçăo. In: Revista de Direito Brasileira, Săo Paulo, v. 10, ano 05, 2015. Disponível em: <http://www.rdb.org.br/ojs/index.php/rdb/ article/view/161>. Acesso em: 05 fev. 2017.

RIFKIN, Jeremy. A Era do Acesso. Traduzido por Maria Lucia G. L. Rosa. Sáo Paulo: MAKRON Books, 2001.

SAMPAIO, José Adércio. Direito à intimidade e à vida privada: uma visăo jurídica da sexualidade, da família, da comunicaçâo e informaçôes pessoais, da vida e da more. Belo Horizonte: Del Rey, 1998.

SARMENTO, Daniel. Direitos fundamentais e relaçôes privadas. Rio de Janeiro: Lumen Juris, 2004.

STRECK, Lenio Luiz. Hermenêutica jurídica e(m) crise: uma exploraçăo hermenêutica da construçâo do Direito. 2. ed. Porto Alegre: Livraria do Advogado, 2000.

0 que é isto - decido conforme minha consciência? - Porto Alegre: Livraria do Advogado Editora, 2010.

Verdade e Consenso. Constituiçăo, Hermenêutica e Teorias. Discursivas. 5. ed. rev. mod. ampl. Săo Paulo: Saraiva, 2006.

. Verdade e Consenso. Constituiçâo, Hermenêutica e Teorias. Discursivas. 5. ed. rev. mod. ampl. São Paulo: Saraiva, 2014.

WARAT, Luis Alberto. 0 Direito e sua Linguagem. 2. ed. Porto Alegre: Sergio Antonio Fabris Editor, 1995.

VIEIRA, Rafael Tomaz de. Decisăo judicial e o conceito de princípio: a hermenêutica e a (in) determinaçâo do direito. Porto Alegre: Livraria do Advogado, 2008. 